\title{
Occurrence of Listeria Species in an Abattoir for Cattle and Pigs in Bosnia and Hercegovina
}

\author{
By S. Loncarevic, A. Milanovic, F. Caklovica, W. Tham and M.-L. Danielsson-Tham
}

Department of Food Hygiene, Veterinary Faculty, Sarajevo, Bosnia and Hercegovina and Department of Food Hygiene, Faculty of Veterınary Medicıne, Swedısh Unıversity of Agricultural Sciences, Uppsala, Sweden.

\begin{abstract}
Loncarevic, S., A. Milanovic, F. Caklovica, W. Tham and M.-L. Danielsson-Tham: Occurrence of Listeria species in an abattoir for cattle and pigs in Bosnia and Hercegovina. Acta vet. scand. 1994, 35, 11-15. - Altogether 496 samples of meat, lymph nodes, process water and swabs from different places in the abattoir were examined for the presence of Listeria spp L monocytogenes was isolated from 31 (6\%) and other Lusteria spp. from $65(13 \%)$ samples $L$. monocytogenes was isolated from 2 of 10 beef meat samples, 4 of 50 pig meat samples and 1 of 21 lymph nodes of pigs. No Listeria bacteria were isolated from lymph nodes of cattle. The highest percentage of Listeria was recovered from the unclean sections (cattle $22 \%$ and pigs $27 \%$ ) and the highest frequency was observed during the winter months.
\end{abstract}

meat; lymph nodes; swabs; Listeria monocytogenes.

\section{Introduction}

Listeria monocytogenes is recognized as a cause of human disease associated with foodborne outbreaks. Outbreaks of listeriosis have been linked to consumption of coleslaw (Schlech et al. 1983), milk (Fleming et al. 1985), and cheese (James et al. 1985; Bille \& Glauser 1988). Although there is no evidence of outbreaks due to consumption of red-meat products, some sporadic cases have been reported. The foods incriminated have been home-made pork sausage (Parodi et al. 1990) and Cajun pork sausage (Anon. 1990). On the other hand, there are many reports of $L$. monocytogenes occurrence in fresh meats, raw meat products and ready-to-eat meat products (see review by Johnson et al. 1990). Survival and growth characteristics of $L$. monocytogenes; growth at refrigeration temperature (Walker et al. 1990), growth in 10\% sodium chloride (Seeliger \& Jones 1984) and relative resistance to heat (Donnelly 1990), as well as its widespread presence in pasture, soil, sewage, poor quality silage, and effluents of abattoirs and meat processing plants, suggest that meat and meat products could be potential vehicles for transmission to man.

The purpose of the present investigation was to study the extent of contamination with $L$. monocytogenes and other Listeria spp. in a cattle and pig abattoir in Bosnia and Hercegovina.

\section{Materials and Methods}

Altogether 496 samples of meat, lymph nodes, drip-water and swabs from different places in the processing plant were examined (Tables 1 , $2 \& 3)$. Samples were collected during the 4 seasons from both the unclean and clean section. The unclean section comprised the stations for bleeding, dehiding or scalding, and evisceration of abdomen and thorax. The clean section included the stations for decapi- 
Table 1. Occurrence of Listeria species in the cattle section in an abattorr in Bosnia and Hercegovina.

\begin{tabular}{lccc}
\hline \multirow{2}{*}{$\begin{array}{l}\text { Type of } \\
\text { swabs / samples }\end{array}$} & $\begin{array}{c}\text { Number of } \\
\text { swabs / samples }\end{array}$ & Number (\%) of positive swabs \\
\cline { 3 - 4 } & & $2(5)$ & Other Listeria spp \\
\hline Unclean section. & 41 & $3(8)$ & $4(10)$ \\
Equipment & 37 & $3(9)$ & $7(19)$ \\
Work surfaces & 32 & $2(7)$ & $5(16)$ \\
Workers' hands & 30 & $0(0)$ & $5(17)$ \\
Surfaces of carcasses & 12 & $10(7)$ & $24(15)$ \\
Drip water samples & 152 & $0(0)$ & $2(5)$ \\
\hline Total & 38 & $1(14)$ & $0(0)$ \\
\hline Clean section. & 7 & $1(2)$ & $4(5)$ \\
Equipment & 40 & $2(2)$ & $28(12)$ \\
Workers' hands & 85 & $12(5)$ & \\
Surfaces of carcasses & 237 & &
\end{tabular}

tation and washing of heads, splitting and washing carcasses.

Meat (Musculus gluteobiceps and M. gracilis), each of $500 \mathrm{~g}$, and lymph nodes (Lnn. mandibularis, Lnn. hepatici, Lnn. intestinales, and Lnn. mammarii or Lnn. inguinalis) surrounded by fat tissue, were sampled from carcasses of 20 cattle and 50 pigs in the clean section 30 min after slaughtering (Table 3). The samples were aseptically removed and put into sterile stomacher bags that were then sealed. Cotton swabs moistened with primary enrichment broth (LEB ${ }_{1}$, McClain \& Lee $1987,1988)$ were used for swabbing surfaces $\left(4 \times 5 \mathrm{~cm}^{2}\right)$ of meat, work surfaces (tables, shelves and floor). Each swab was then put into a tube containing $10 \mathrm{ml} \mathrm{LEB}_{1}$. Drip water from the washed carcasses was collected and $25 \mathrm{ml}$ was transferred to a $100 \mathrm{ml}$ screw cap bottle containing $25 \mathrm{ml}$ of LEB $_{1}$ (Tables 1 \& 2). All samples were transferred to the laboratory under refrigeration $\left(+4^{\circ} \mathrm{C}\right)$ and examined the same day. Isolation and identification of Listeria spp. were done according to McClain \& Lee $(1987,1988)$. From the meat and lymph node samples respectively, $25 \mathrm{~g}$ were cut out and macerated in a stomacher together with $225 \mathrm{ml} \mathrm{LEB}_{1}$. The macerates, the swab samples and the water samples were incubated at $30^{\circ} \mathrm{C}$ for $24 \mathrm{~h}$. Then $0.1 \mathrm{ml} \mathrm{LEB}{ }_{1}$ was transferred to $10 \mathrm{ml}$ secondary enrichment broth (LEB 2 , McClain \& Lee 1987, 1988) and incubated at $30^{\circ} \mathrm{C}$ for $24 \mathrm{~h}$. From these $\mathrm{LEB}_{2}, 0.1 \mathrm{ml}$ was directly streaked onto LPM (Lithium chlorid-phenylethanol moxalactam) agar plates, and additionally $0.1 \mathrm{ml}$ was streaked after treatment with $0.25 \%$ $\mathrm{KOH}$ solution. The LPM agar plates were incubated at $30^{\circ} \mathrm{C}$ for $24 \mathrm{~h}$.

Five presumptive Listeria colonies were picked from each "positive" plate and streaked onto sheep blood agar for control of purity and hemolytic activity. The strains were tested for Gram reaction, catalase production and motility. For identification of species the following tests were used: CAMP (Christie, Atkins, Munch-Petersen), MR (Methyl Red), VP (Voges-Proskauer), hydrolysis of urea and esculin, nitrate reduction and acid from rhamnose, mannitol, xylose, maltose and glucose. 
Table 2. Occurrence of Listeria species in the pig section in an abattoir in Bosnia and Hercegovina.

\begin{tabular}{lccc}
\hline \multirow{2}{*}{$\begin{array}{l}\text { Type of } \\
\text { swabs / samples }\end{array}$} & $\begin{array}{c}\text { Number of } \\
\text { swabs / samples }\end{array}$ & \multicolumn{2}{c}{ Number (\%) of positive swabs } \\
\cline { 3 - 4 } Unclean section. & 35 & $1(3)$ & Other Listeria spp \\
Equipment & 8 & $1(12)$ & $5(14)$ \\
Work surfaces & 20 & $3(15)$ & $1(12)$ \\
Workers' hands & 28 & $3(11)$ & $4(20)$ \\
Surface of carcasses & 12 & $1(8)$ & $8(29)$ \\
Drip water samples & 103 & $9(9)$ & $19(18)$ \\
\hline Total & 25 & $1(4)$ & $2(8)$ \\
\hline Clean section: & 10 & $1(10)$ & $2(20)$ \\
Equipment & 22 & $1(4)$ & $8(18)$ \\
Workers' hands & 57 & $3(5)$ & $27(17)$ \\
Surface of carcasses & 160 & $12(7)$ & \\
\hline Total & & &
\end{tabular}

\section{Results and discussion}

In the present study, L. monocytogenes was isolated from $31(6 \%)$ of the samples (meat, lymph nodes, process water and swabs) and other Listeria spp. from 65 (13\%) (Tables 1, 2, $3)$. There were no cases where both L. monocytogenes and "other Listeria spp." were isolated from the same sample. Thus "other Listeria spp." did not indicate the presence of $L$. monocytogenes.

L. monocytogenes was isolated from $10 \%$ of the beef and $8 \%$ of the pig meat samples, while other Listeria spp. were isolated from $10 \%$ in both cases (Table 3 ). Reports of the incidence of Listeria spp. in meat sampled in meat plants are rare. However, in a paper from New Zealand, L. monocytogenes was reported to be present in $20 \%$ of 25 beef boneless cuts in a meat plant and in $68 \%$ of 25 pork cuts in retail display meats (Lowry \& Tiong 1988). In a Swiss investigation, $L$. monocytogenes was isolated from $17 \%$ of 18 raw beef samples, and from $13 \%$ of 31 raw pork meat samples (Breer \& Breer 1988). However, it is not clear whether these samples were collected at the meat plant or at retail outlets.

In the present study, L. monocytogenes was isolated from 5\% and other Listeria spp. from $14 \%$ of the investigated porcine lymph nodes, but not from the bovine lymph nodes. In an investigation from Togo, Africa, hemolytic Listeria bacteria were isolated from $2 \%$ of 104 and $1 \%$ of 118 intestinal lymph nodes from apparently healthy slaughter pigs and cattle, respectively (Hohne et al. 1975). As lymph nodes are included in the processing of meat they may be a source of Listeria (Johnson et al. 1990). L. monocytogenes was isolated from $0-8 \%$ and other Listeria spp. from $0-19 \%$ of environmental samples (work surfaces and equipment) from the cattle section (Table 1). In the New Zealand investigation, L. monocytogenes was present in $6(30 \%)$ and other Listeria spp. in $3(15 \%)$ environmental samples (work surfaces and knives) at a beef plant (Lowry \& Tiong 1988).

The highest percentage of Listeria positive samples was found during the winter (Table 4). According to Seeliger (1969) and Arm- 
Table 3 Listeria incidence in samples of meat and lymph nodes in an abattoir in Bosnia and Hercegovina.

\begin{tabular}{lccc}
\hline \multirow{2}{*}{$\begin{array}{l}\text { Type of } \\
\text { samples }\end{array}$} & $\begin{array}{l}\text { No.of samples } / \\
\text { No.of carcasses }\end{array}$ & \multicolumn{2}{c}{ Number (\%) of positive samples } \\
\cline { 3 - 4 } & & & L monocytogenes \\
Beef: & $20 / 20$ & $2(10)$ & Other Listeria spp \\
Meat & $8 / 8$ & $0(0)$ & $2(10)$ \\
Lymph nodes & $28 / 20$ & $2(7)$ & $2(7)$ \\
\hline Total & $50 / 50$ & $4(8)$ & $5(10)$ \\
\hline Plg: & $21 / 21$ & $1(5)$ & $3(14)$ \\
Meat & $71 / 50$ & $5(7)$ & $8(11)$ \\
Lymph nodes & $99 / 70$ & $7(7)$ & $10(10)$ \\
\hline Total & & &
\end{tabular}

strong (1991), listeriosis in animals is most common in winter.

The abattoir investigated has an outdated slaughtering technique, e.g. dehiding of the bovine in the horizontal position by hand, and this may contribute to the spread of L. monocytogenes. Technical mistakes, e.g. perforation of udders or abdominal organs, are other sources of contamination. Therefore, it is indispensable that oversights are reduced, particularly at the dehiding, scalding and evisceration stations. Good hygienic practice is very important to reduce contamination risks. To avoid cross-contamination, knives and other instruments should be disinfected regularly. Strict separation of personnel working in the unclean section from those in the clean section, and the avoidance of contacts between fixed installations and carcasses, are other points of great importance.

\section{References}

Anonymous: CDC links Cajun pork sausage to Listeriosis case; product recalled. Food Chemic. News. 1990, Jan. 1., p. 35.

Armstrong D. Listeria monocytogenes Infections. In: Evans AS, Brachman PS (eds.): Bacterial Infections of humans - Epidemiology and Control, 2nd ed. Plenum Publ. Co, New York, 1991, pp. 395-402.

Bille J, Glauser M-P: Listeriose - Situation in der Schweiz (Listerıosis in Switzerland). Bulletın des Bundesamtes fur Gesundheitswesen/Bulletin de l'Office fédéral de la santé publique 1988 , no 3 , 28-29.

Breer C, Breer G: The isolation of Listeria spp. in meat and meat products. Proc. 34th Int. Congress Meat Sc1. Technol., Part B. 1988, pp. 520521.

Donnelly CW: Resistance of Listeria monocytogenes to heat. In: Miller AJ, Smith JL, Somkutı GA (eds.) Foodborne Listeriosis. Elsevier, The Netherlands, 1990. pp. 189-193.

Fleming DW, Cochı SL, Mac Donald KL, Brondum $J$, Hayes PS, Plikaytıs BD, Holmes MB, Andurier $A$, Broome $C V$, Reingold $A L \cdot$ Pasteurized milk as a vehicle of infection in an outbreak of listeriosis. New Eng. J. Med. 1985, 312, 404-407.

Hohne K, Loose B, Seeliger HPR Recent findings of Listeria monocytogenes in slaughter anımals of Togo (West Africa ). In. Woodbıne M (ed.) Problems of listeriosis. Leicester University Press, Leicester, England, 1975, 127-130.

James SM, Fannin SL, Agge BA, Hall B, Parker E, Vogt J, Rung G, Williams J, Lieb L,Salminen C, Prendergast T, Werner SB, Chin J. Listeriosis outbreak associated with Mexican-style cheese. Morbid. Mortal. Weekly Report 1985, 34, 357359.

Johnson JL, Doyle MP, Cassens RC $\cdot$ Listeria monocytogenes and other Listeria spp. in meat and meat products. J. Food Protect. 1990, 53, 81-91. 
Table 4 Listeria incidence on the slaughterıng and primary processing lines for cattle and pigs in different seasons in an abattoir in Bosnia and Hercegovina.

\begin{tabular}{|c|c|c|c|c|c|c|}
\hline \multirow[t]{2}{*}{ Season } & \multicolumn{3}{|c|}{ Cattle section } & \multicolumn{3}{|c|}{ Pig section } \\
\hline & $\begin{array}{c}\text { No of } \\
\text { samples } \\
\text { and swabs }\end{array}$ & $\begin{array}{c}\text { No }(\%) \text { of } \mathrm{p} \\
L \text { mono- } \\
\text { cytogenes }\end{array}$ & $\begin{array}{l}\text { sitive samples } \\
\text { other } \\
\text { Listeria spp }\end{array}$ & $\begin{array}{l}\text { No of } \\
\text { samples } \\
\text { and swabs }\end{array}$ & $\begin{array}{c}\text { No. }(\%) \text { of } \mathrm{p} \\
\text { L mono- } \\
\text { cytogenes }\end{array}$ & $\begin{array}{c}\text { Sitive samples } \\
\text { other } \\
\text { Listeria spp }\end{array}$ \\
\hline Autumn & 53 & $4(8)$ & 7 (13) & 58 & $5(9)$ & $9(16)$ \\
\hline Winter & 78 & $7(9)$ & $11(14)$ & 64 & $8(13)$ & $11(17)$ \\
\hline Sprıng & 74 & $2(3)$ & $7(10)$ & 67 & $3(5)$ & $10(15)$ \\
\hline Summer & 60 & $1(2)$ & $5(8)$ & 42 & $1(2)$ & $5(12)$ \\
\hline Total & 265 & $14(5)$ & $30(11)$ & 231 & $17(7)$ & $35(15)$ \\
\hline
\end{tabular}

Lowry PD, Tiong I· The incidence of Listeria monocytogenes in meat and meat products: Factors affecting distribution. Proc. 34th Int. Congress Meat Scı Technol., part B. 1988, 528-530.

McClain D, Lee $W H \cdot$ Development of USDA - FSIS method for isolation of Listeria monocytogenes from raw meat and poultry. J. Ass. Off. Anal. Chem. 1988, 71, 660-664.

McClain D, Lee WH. Isolation and identification of Listeria monocytogenes from meat. USDA / FSIS / Microbiology Division, Laboratory Communication No. 57-9/9, 1987.

Parodı M, Marıno P, Balzarettı C, Maurı A, Caınarca $M$, Cantonı $C$ : Listeriosı sporadica e trasmissione da carne di mariale. (A case report of sporadic listeriosis related to pork-meat in healthy man). G Mal Infett. Parassit. 1990, 42, 115-116.

Schlech WF, Lavigne PM, Bortolussi RA, Allen AC, Haldane EV, Wort AJ, Martın RS, Hightower AW, Johnson SE, King SH, Nicholls ES, Broome $C V$ : Epidemic listeriosis: Evidence for transmission by food. New Eng. J. Med. 1983, 308, 203.

Seeliger HPR, Emmerlıng P, Emmerlıng H. Listeriosis in Germany Germ. Med. Mth 1969, 14, 157163.
Seeliger HPR, Jones D: Genus Listeria. In: Sneath PHA, Maier NS, Sharpe ME, Holt JG (eds.): Bergey's Manual of Systematic Bacteriology, Vol 2. Williams and Wilkıns, Baltımore, 1984, pp. 1235-1245.

Walker SJ, Archer P, Banks JG. Growth of Listeria monocytogenes at refrigeration temperatures. J. Appl. Bact. 1990, 68, 157-162

\section{Sammanfattning \\ Forekomsten av Listeria species $\imath$ ett slakterl for not- kreatur och svin ı Bosnien och Hercegovina}

Totalt 496 prover, bestående av kott, lymfknutor, processvatten och svabbprover från olıka platser på slakteriet, analyserades på forekomst av Listerıa spp L monocytogenes isolerades från 31 (6\%) och andra Listerıa spp från $65(13 \%)$ av proverna. $L$. monocytogenes isolerades från 2 av 10 prover från notkott, 4 av 50 prover från svınkott och en av 21 svinlymfknutor. Inga Listerıa-bakterier påvisades 1 notlymfknutor. Hogsta andelen Lusteria-bakterier isolerades från de orena avdelnıngarna. Hogst frekvens noterades under vintermånaderna.

(Recelved September 14, 1993; accepted September 21, 1993)

Reprints may be requested from: S. Loncarevıc, Department of Food Hygıene, Faculty of Veterınary Medıcine,

Swedish Unıversity of Agricultural Sciences, Box 7009, S-750 07 Uppsala, Sweden. 
